268

.U5

1913

RSPORT ON AN INVESTIGATION

AS TO THE RA'I OF TAX ON OIEOMARGERINE. 


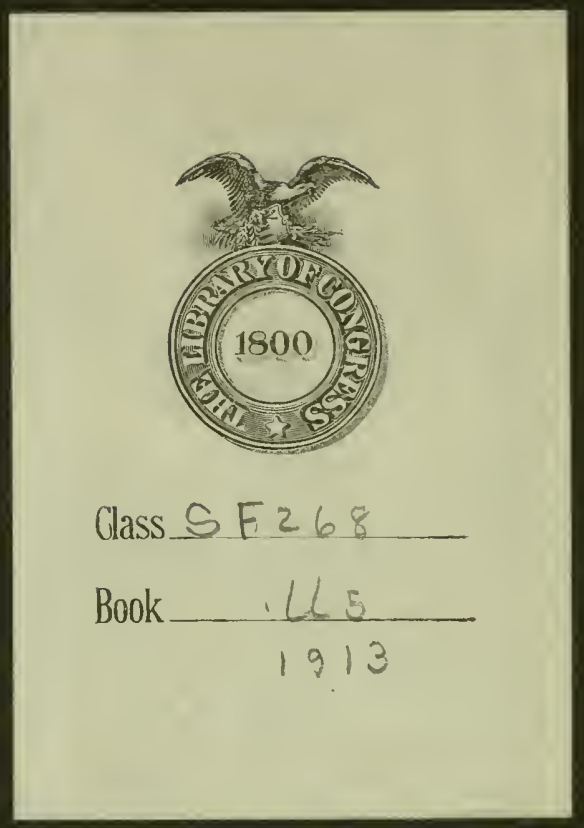




$\left.\begin{array}{c}62 \mathrm{D} \text { Congress, } \\ 3 d \text { Session. }\end{array}\right\}$ HOUSE OF REPRESENTATIVES. $\left\{\begin{array}{c}\text { RePoRT } \\ \text { No. } 1572 .\end{array}\right.$

\author{
OLEOMARGARINE TAX.
}

Ferruary 25, 1913.- - Referred to the House Calendar and ordered to be printed.

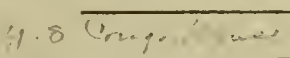

Mr. Cox, from the Committee on Expenditures in the 'Treasury Department, submitted the following

\title{
REPORT ON AN INVESTIGATION AS TO THE RATE OF TAX ON OLEOMARGARINE.
}

For some time a controversy has existed between the Treasury Department and certain manufacturers of oleomargarine as to the rate of tax which should be imposed by the department on oleomargarine made by certain manufacturers thereof, duing the years 1911 and 1912. Under the law (act of 1902) oleomargarine is taxed at the rate of one-fourth cent per pound, unless said oleomargarine is artificially colored that causes it to look like butter of any shade of yellow, in which event it shall bear a tax of 10 cents per pound.

During the investigation the committee heard a great deal of evidence, oral and documentary, on the subject as to whether or not the Treasury Department should accept in full the amounts hereafter set out, in lieu of the amounts claimed by the department, as the amount for which it could lay an assessment on the manufacturers thereof. The facts out of which this controversy grew, originated with the manufacturers of oleomargarine using a colored cottonseed oil in the manufacture of oleo, known as fulvous oil, golden yellow, butter oil, etc.

The committee finds the following to be the facts in said controvel'sy:

1. The committee finds that the manufacturers of oleomargarine for the past 10 years have used every method known to science to get an oil not prohibited in the manufacture of oleo, by reason of the unhealthfulness of the article or the color of the finished commodity, so not to subject the oleo to a tax of 10 cents per pound; and in their investigations the manufacturers through their own bureaus of chemistry, aided and assisted by private chemists, have experimented with sesame oil, mustard-seed oil, peanut oil soy-bean oil, etc. During the same time the refiners of cottonseed oil have conducted scientific investigations with a view of erolving a process of refining cottonseed oil which when refined would retain its natural color as found in its crude state, only cottonseed oil being used in the manufacture of 
oleo; but all of said experiments and investigations have proven fruitless, either because of the fact of the high expense attached to said processes or to the fact that the finished commodity failed by reason of the taste thereof to meet the demands of the trade.

2. The committee finds that unrefined cottonseed oil is hiohly colorerl, and that the normal refined cottonseed oil is colorless, white. or a tinge of yellow, and that the Ionisville r'otton Oil ('o., an oil refinery, claimed to have disenvererl a secret process of refining cottonseed oil which would give it a color and when refined was free from artificial coloring matter, and that sair company sold large amounts of this oil to the manufactmers of oleo, which was used by them in the manufacture of said commolity.

3. That said oil was sold unler the brand or trade name of fulvous oil, butter oil. golden yellow, cte., made by the Louisville ('otton Oil Co., and that during said time the manufactures's of olen bought other oils from the Penn Oil of Supply ('o. and the R. 1). Winship C'o., the latter as a broker of the Pemn Oil \& Supply ('o. but all of said oil was treate i with a riew of giving it a color.

4. That some of the mamufacturers of oleo submitted samples of this colored oil to the department for analysis and examination before using the same in the manufacture of oleo, and at the time of submitting said nil for examination sought permission of the department to use the same in the mamufacture of oleo at the rate of onc-fourth cent peir pound.

5. That the department at the timc said oil was submitted to it, or soon thereafter, examined the same for arificial coloring matter and found none, and it so expressed itsolf to Armour \& Co., who submitted said samples. But it informed said manufacturer that it believed said oil to be artificially treated or colored, and at the same time and later informed the manufacturers that it would not undertake to prescribe a formula for their commodity, but should a colored oleo appear on the market it would be subject to investigation, and if found to contain artificial coloring matter, either as a result of coloring matter in the oil or in any other ingredient, it would be subject to a tax of 10 cents per pound.

6. The committee further fincls that a number of other oleo manufacturers from time to time sought to get the department to give its permission to use said colored oil and thereby procure immunity from said department against the 10 cents per pound tax, but the lepartment persistently refused to grant immunity and continued to inform the manufacturers that if it used said oil it would be at their peril, and in the event a colored finished commodity appeared upon the markets looking like butter, that it would be subject to investigation and if found to contain artificial coloring matter the same would be taxed at the rate of 10 cents per pound.

7. That the Treasury Department has no conceru whatever in the ingredients entering into oleo, except to see that no artificial coloring matter enters into the finished commodity, which would give it the shade or color of butter, either through the ingredients entering into the finished commodity or the finished commodity itself its concern being only over tax liabilities or the revenues of the Government.

8. That colored oleo, looking like butter during the years 1911 and 1912 appeared upon the market in the ordinary and usual chan- 
nels of trade mpon which a tax of ome-fourth cent per pound was paid.

9. A sample of colored oleo during the month of January, 1912 , was submitted to the Burean of Chemistry in the Agricultural Department for examination, and said bureau transferred the same to the Bureau of Animal Industry in the same department, where it was chemically analyzed and the fact revealed that said oleo was artificially colored and that the colorant used was sulphur.

10. That the Bureau of Animal Industry has nothing whatever to do with the revenues of the Govermment, its function being to cook after the healthfulness of the commodity. While it permitted cottonseed oil as an ingredient of oleo, it prohibited the use of sulphur.

11. That the Bureau of Animal Industry, looking after the healthfulness of the commodity, in the month of February through an order issued by it, prohibited the use of sulphur in cottonseed oil used in the manufacture of oleo or in the finished commodity.

12. That after sulphur was discovered in the oleo as herein set out a large number of samples of fulvous oil, golden yellow, butter oil, etc., were examined; in some of said samples sulphur was found and in some no sulphur was found. But all of said oils so examined presented a color showing artificial treatinent.

13. The committee finds that in the process of refining cottonsecd oil it is possible by heating the same and while in its heated condition to pass sulphur or sulphur fumes through said oils and thereafter by a process of washing or refining wash or blow the sulphur out of it, and yet the oil retain an artificial color.

14. The committee further finds the first tine the Bureau of Animal Industry examined said oil or oleo for sulphur was in January, 1912, and found the same by making or applying what is known as the silver test - a standard test for sulphur.

15. The committee finds that the Treasury Department at the time said colored cottonseed oil was submitted to it examined the same for coal tar and regetable color and failed to find any such coloring matter in said oil. But the committee finds that after January, 1912, the Burcau of Chemistry, in the office of the Commissioner of Internal Revenue, on an examination of samples of this oil and oleo found the same to contain abnormal quantities of sulphur.

16. The committee finds that the colored matter used by the Iuvisville Cotton Oil Co., the Penn Oil Supply Co., and the R. D. Winship Co., the latter as a broker for the Penn Oil Supply Co. and the Sherman Oil Co.-engaged during the years 1911 and 1912 in manufacturing and refining cottonseed oil, and which oil was sold by them to the manufacturers of oleo-was artificially treated with sulphur by adding the sulphur to said oil during the process of refining the same, or by blowing sulphur fumes through the same when said oil was in a heated condition, and which sulphur and sulphur fumes being passed through said oil while in a heated condition gave to the same a color, and which when manufactured into oleomargarine gave a shade of color to said oleo, causing it to look like butter. And this artificially treated oil was sold to the mannfacturers of oleo at an increase of from 1 to 2 cents per pound.

17. The committee finds that the department obtained from the hooks of the manufactnrers of oleomarcarine, the names of whom are 
horeinafter set out. the total quantity of treated oil used by them in the manufacture of oleo, and that this was corroborated and reenforced by the rocords and books of the railroad companies that shipped said oil orer their lines to said manufacturers, and this was further fortified and supported by the books of the refiners of cottonseed oil, to wit, the Louisville Cotton Oil Co.. the Penn Oil Supply Co.. and the R. D. Winship Co.

18. The committee finds that the department called upon and asked the manufacturers to submit their formulas from which said oleo was manufactured and that said manufacturers fully complied with said request and furnished to the depurtment their said formulas, which said formulas gave the per cent of cottonseed oil that went into the manufacture of oleo; and from the total mount of artificially treated cottonseed oil found by the department to have been used by the manufacturers of oleo, the department found that the manufacturers of oleo made and manufactured amounts thereof sufficient to make the total assessed liability amount to the several sums hereinafter set ont against each one of said manufacturers, to wit:

Moxley Gu.....

U. S. Butterine $C^{\prime}$

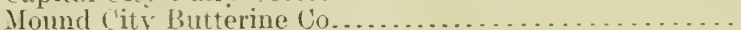

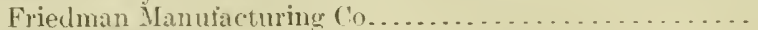

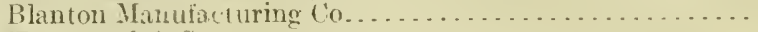

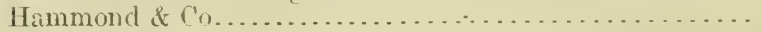

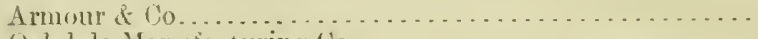

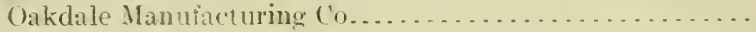

() bio Butterine ('o. .

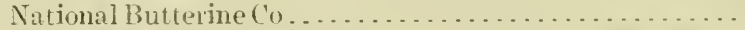

Vermolunt Mandtituring (
$\$ 334.167 .21$

$6 \mathrm{~S}, 321.3 \mathrm{~S}$

$266,434.93$

4. 690.00

$79,875.91$

6. 876.01

$213,657.50$

$122,886.85$

$11,371.98$

$126,331,3: 3$

$11,658.46$

36S. 16

Total.

$1,246,628.62$

19. The committee finds from the eridence that the above amounts are due the Govermment by reason of said oleomargarine being artificially colored and taxable at the rate of 10 cents per pound instead of one-fourth cent per pound, which latter tax the manufacturers paid.

14. And the eommit tee finds that the following manufarturers have offered as a compromise and full settlement in licu of the amount proposed to be assessed against them by the department. to wit:

Armour \& Co.

$\$ 10,000$

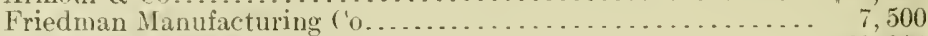

G. H. Hammond \& Co............................ 20,000

$\Pi$ m. J. Moxley ................................. 25, 000

U. S. Butterine Co............................. . 6,000

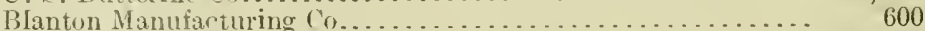

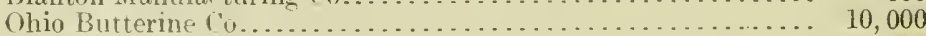

Capital (ity I Iary . . . . . . . . .

Total amount offered in compromise and settlement in full.

\section{RECOMMENUATIONS.}

1. The commitlere recommends against the acceptance of said smm of $\$ 101,100$ by the department in full settlement and in compromise of the amounts found by the committee to be due the Government as set forth in the finding 18 . 
2. The committee recommends that the department nake an assessment against each one of the manufacturers as set forth in finding 18 for the amounts set forth therein.

IT. E. Cox. CTaimun.

Views of Mr. Goeke, Mr. Lobeck, and Mr. Callaway.

We, the undersigned members of the committee, recommend:

1. That the offered compromise be rejected.

2. We recommend that the department make an assessment in one of the cases, selected by the department, and require that it be paid in full, and party paving in bring suit to recover' same, all other parties agreeing to abide judgment in case tried in proportion to their respective liahilities.

J. H. GOEke.

C. O. LОВЕСК.

Oscar Callatway.

\section{MINORITY REPORT.}

Views of Mr. Hill and Mr. Youvi.

We, the undersigned minority members of the committee, after a thorough examination of the testimny, can not concur either in the presentation of the case by the majority or in either of the foregoing recommendations in their entiret 5 .

We are first of the opinion that as the natter is now in the hands of the executive department of the Gorernment, in enmpliance with the law and subject to its disposition and adjustment, no recommendation by this committee is necessary.

If such recommendation is desired. we would advise either that a test case be made in accordance with the recommendation of the majority of the majority members, or that the whole case be compromised in accordance with the recommendation of the Solicitor of the Bureau of Internal Revemue, in the discretion of the Secretary of the Treasury, and we refer to the able and exhaustive review of the case by the Solicitor in justification of our final recommendation.

E. J. HILL.

11. O. Youxg. 



MAKERS

SYRACUSE, MY,

FAT. JAH. 21, 1800 


\section{LIBRARY OF CONGRESS}

||

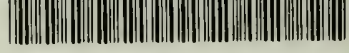

0000891323 ? 